\title{
Isolation, identification and characterization of a novel elastase from Chryseobacterium indologenes
}

\author{
Yunlong Lei ${ }^{1} \cdot{\text { Peipei } \mathrm{Zhao}^{1} \cdot \text { Chenglei }^{\mathrm{Li}^{1}} \cdot \text { Haixia Zhao }}^{1}$. \\ Zhi Shan ${ }^{1} \cdot$ Qi Wu ${ }^{1}$
}

Received: 25 January 2018/Accepted: 27 March 2018/Published online: 21 April 2018

(C) The Korean Society for Applied Biological Chemistry 2018

\begin{abstract}
Elastase is a type of protease that specifically degrades elastin. It has broad application prospects in medicine, food industry, and daily-use chemical industry. In this study, we isolated a bacterial strain WZE87 with high elastin-hydrolysis activity, which was identified as Chryseobacterium indologenes based on morphology, physiological and biochemical characteristics, and $16 \mathrm{~S}$ rDNA sequence analysis. The elastase produced by this strain was purified by three steps: ammonium sulfate precipitation, Q-Sepharose fast-flow anion-exchange chromatography, and Sephadex G-75 gel-filtration chromatography. The purified elastase was $2376.5 \mathrm{U} / \mathrm{mg}$ in activity (a 8.3-fold increase in specific activity), and the recovery was $5.8 \%$. Its molecular mass was estimated to be $26 \mathrm{kDa}$ by sodium dodecyl sulfate-polyacrylamide gel electrophoresis. This enzyme was stable in the $\mathrm{pH}$ range of $5.0-10.5$ at $37^{\circ} \mathrm{C}$. The optimal temperature and $\mathrm{pH}$ were $37^{\circ} \mathrm{C}$ and 7.5 , respectively. The activity of this elastase was found to decrease when the temperature was higher than $50{ }^{\circ} \mathrm{C}$. The activity was also inhibited by $\mathrm{Zn}^{2+}, \mathrm{Fe}^{2+}$, $\mathrm{Fe}^{3+}$, and $\mathrm{Mn}^{2+}$ ions. The specific hydrolytic ability of this enzyme was similar to that of papain on substrates like gelatin, casein, soybean-isolated protein and bovine hemoglobin. However, this elastase preferentially hydrolyzed elastin in a protein mixture because of its specific adsorption. Considering its promising properties, this protease may be considered a potential candidate for applications in related industries.
\end{abstract}

Qi Wu

wuqi@sicau.edu.cn; 1522308900@qq.com

1 College of Life Science, Sichuan Agricultural University, Xin Kang Road No. 46, Ya'an City 625014, Sichuan Province, People's Republic of China
Keywords Chryseobacterium indologenes · Elastase · Enzyme property · Protein hydrolysis specificity · Purification

\section{Introduction}

Elastin is an insoluble protein that exists in the extracellular matrix and connective tissues. It is crosslinked with nonpolar amino acid residues, such as Ala, Leu and Ile, and is combined with microfibrils to form elastic fibers in vivo $[1,2]$. Elastase is an endopeptidase that hydrolyzes insoluble elastin [3, 4]. Because of its hydrolytic bias for peptide bonds at the carboxyl end of neutral aliphatic amino acids, elastase shows a high specificity for elastin. It hydrolyzes insoluble elastin much more efficiently than other proteases and has been widely applied in many fields, such as curing hyperlipidaemia and arteriosclerosis in medicine [5].

In China, the people's favorite parts of livestock, apart from pork and beef, are the tendon, skin, and stomach tissues. However, the rich elastin in these tissues strongly limits the taste and texture of these foods. Accordingly, Chen et al. [6] reported the tenderization of pork by elastase by testing the meat shear force. Sachar et al. [7] reported the tenderization and sensory evaluations of beef by elastase by improving meat mouthfeel and dish flavor. Hence, elastase has become a promising meat tenderizer.

Since the reports by Balo and Banga that protease from the pancreas could hydrolyze elastin [8,9], elastase has been widely isolated from bovine, moose, North Atlantic salmon, and ovine pancreas [10-12]. However, the high cost of elastase sourced from animals has impeded its application. Microbial elastase serves as a preferred option not only because of the low cost and the extensive 
distribution of elastase in microorganisms, but also the ease to genetically manipulate enzyme properties for various requirements [3]. Since the first isolation and purification of elastase from Flavobacterium elastolyticum by Ines et al. [13], elastase from Flavobacterium sp. R-102-87, Bacillus alcalophilus Ya-B, Vibrio cholerae, and Micrococcus luteus was reported which are amenable to industry production [7, 12, 14, 15].

In this study, we describe the purification and characterization of the elastase produced by the strain Chryseobacterium indologenes WZE87. Particularly, we analyzed and evaluated its hydrolysis specificity toward different protein substrates. This research provides a valuable reference for the further application of elastase in meat tenderization and animal protein process in future.

\section{Materials and methods}

\section{Strain identification}

An elastase-producing bacterium, designated strain WZE87, was isolated from the mud of a meat market in Ya' an city. It was grown in Luria-Bertani (LB) broth $(1.0 \%$ w/v peptone, $0.5 \%$ w/v yeast extract, $0.5 \%$ w/v NaCl, $1.5 \%-2.0 \% \mathrm{w} / \mathrm{v}$ agar powder, $\mathrm{pH} 7.0$ ) for $24 \mathrm{~h}$ at $37{ }^{\circ} \mathrm{C}$. Bacteria with the highest $\mathrm{HC}$ value (the ratio of hydrolysis halo to colony diameter) were then isolated from the growth medium (culture conditions: $60 \mathrm{~h}$ at $37^{\circ} \mathrm{C}$ in bovine tendon powder (BTP) medium consisting of $1.0 \%$ w/v BTP, $1.5 \%-2.0 \%$ agar powder, $\mathrm{pH}$ 7.0-7.5). The physiological and biochemical properties were identified using a VITEK2 automated bacterial identification system (Biomerieux Biotech Co., Ltd., France), and then 16S ribosomal DNA (rDNA) was amplified. Primers are as follows:

upstream primer 27F(5'-AGAGTTTGATCCTGGCTCAG- $3^{\prime}$ )

downstream 1492R(5'-TACGG(C/T)TACCTTGTTACGACTT-3').

\section{Elastase activity assay}

Elastase activity was measured using a modification of a previous method [5]. Orcein elastin $(20 \mathrm{mg})$ in Tris- $\mathrm{HCl}$ buffer (6 mL of $200 \mathrm{mM}$, pH 8.0) was mixed with standard elastase solution $(0.1 \mathrm{~mL}$ of $1500 \mathrm{U} / \mathrm{mL})$ and incubated for $1 \mathrm{~h}$ at $37{ }^{\circ} \mathrm{C}$. Tris- $\mathrm{HCl}$ buffer $(200 \mathrm{mM}$, pH 8.0, no enzyme and substrate) was used as the control group. A standard curve was generated from the reaction where elastase hydrolyzed orcein elastin. One unit of elastase activity was defined as the amount of enzyme required to hydrolyze $1 \mathrm{mg}$ elastin per minute at $37^{\circ} \mathrm{C}$.

\section{Elastase purification}

Strains were grown in seed medium $(0.5 \%$ glucose, $1.0 \%$ peptone, $0.5 \%$ yeast extract, $0.5 \% \mathrm{NaCl}, \mathrm{pH} 7.0$ ) for $18 \mathrm{~h}$ at $30{ }^{\circ} \mathrm{C}$ and then inoculated in fermentation medium (0.5\% glucose, $1.0 \%$ peptone $0.4 \% \mathrm{w} / \mathrm{v}$ cornflour, $0.4 \%$ BTP, $0.1 \%$ w/v $\mathrm{K}_{2} \mathrm{HPO}_{4} \cdot 3 \mathrm{H}_{2} \mathrm{O}, 0.05 \% \mathrm{w} / \mathrm{v} \mathrm{MgSO}_{4} \cdot 7 \mathrm{H}_{2} \mathrm{O}$, $\mathrm{pH} 7.0$ ) for $26 \mathrm{~h}$ at $30{ }^{\circ} \mathrm{C}$. After centrifugation of the culture, the supernatant was retained as the crude enzyme. The crude enzyme samples were precipitated separately with $25,30,40,50,60,70,75$, and $80 \%$ ammonium sulfate saturation to ascertain the optimal precipitation saturation by measuring the elastase activity of the supernatant. Then the enzyme sample was precipitated with the optimal precipitation saturation and dissolved in Buffer A $(200 \mathrm{mM}$ Tris-HCl, $\mathrm{pH}$ 7.5) and concentrated by PEG-20,000. The concentrated protein $(2 \mathrm{~mL})$ was subjected to a Q-Sepharose fast-flow chromatography column $(1.5 \times 20 \mathrm{~cm})$ after pre-equilibration with distilled water and Buffer $\mathrm{A}$, which was eluted with a linear gradient of $1 \mathrm{mM} \mathrm{NaCl}$, at a flow rate of $3 \mathrm{~mL} / \mathrm{min}$. Afterward, the active peak $(1 \mathrm{~mL})$ was pooled and applied to a Sephadex G-75 column $(1.5 \times 50 \mathrm{~cm})$ previously equilibrated with Buffer A. Specific protein was eluted with Buffer A at a flow rate of $0.5 \mathrm{~mL} / \mathrm{min}$. Finally, aim fractions with active elastase activity were collected, concentrated, and refrigerated at $4{ }^{\circ} \mathrm{C}$ for further analysis. The protein concentration was determined by the method of Marion et al. [16]. Gradient concentrations of bovine serum albumin (BSA) were used to make a standard curve. All the purification steps were conducted at temperatures not exceeding $4{ }^{\circ} \mathrm{C}$.

\section{Elastase molecular mass determination}

Sodium dodecyl sulfate-polyacrylamide gel electrophoresis (SDS-PAGE) was performed with $12 \%$ polyacrylamide gel [15]. The standard molecular weight markers were purchased from Takara Biotechnology Co., Ltd. (Da Lian, Liaoning province, China). The specific fraction $(10 \mu \mathrm{L})$ was added into each lane of the gel. The protein bands were stained with Coomassie Brilliant Blue R-250.

\section{Enzyme characterization}

The optimal reaction temperature was determined by measuring the elastase activity in a water bath at different temperatures $(20,25,30,37,45,50,55,60,65,70$ and $80{ }^{\circ} \mathrm{C}$ ). For the thermostability analysis, elastase activity was measured in the range of $30-80{ }^{\circ} \mathrm{C}$. 
To determine the optimal reaction $\mathrm{pH}$ of the elastase, the enzyme was mixed with $200 \mathrm{mM}$ buffer (sodium acetate, sodium phosphate, Tris- $\mathrm{HCl}$, boric acid, or sodium carbonate) in a $\mathrm{pH}$ range of $3.5-10.5$. To analyze the stability of the elastase at different $\mathrm{pH}, 0.1 \mathrm{~mL}$ of enzyme solution was added to $0.6 \mathrm{~mL}$ of $20 \mathrm{mM}$ Tris- $\mathrm{HCl}$ buffer in a $\mathrm{pH}$ range of 3.5-12.5 and left for $24 \mathrm{~h}$ at room temperature. Enzyme activity was measured at the optimal condition in $200 \mathrm{mM}$ Tris-HCl buffer.

The effect of metal ions on the enzyme activity was investigated by separately adding three monovalent ions $\left(\mathrm{Na}^{+}, \mathrm{K}^{+}\right.$, and $\left.\mathrm{Li}^{+}\right)$, five divalent ions $\left(\mathrm{Zn}^{2+}, \mathrm{Mn}^{2+}, \mathrm{Ca}^{2+}\right.$, $\mathrm{Mg}^{2+}$, and $\mathrm{Fe}^{2+}$ ) and $\mathrm{Fe}^{3+}$ at the final concentration of $5 \mathrm{mM}$ of the reaction mixture. Meanwhile, the influence of chemical reagents on elastase activity was also tested by $5 \mathrm{mM}$ ethylenediaminetetraacetic acid (EDTA), $5 \mathrm{mM}$ sodium dodecyl sulfate (SDS), and $0.01 \mathrm{mM} \beta$-mercaptoethanol. The residual activities were determined as a percentage of the activity in the control sample without any extra additive, measured at optimum temperature and $\mathrm{pH}$.

\section{Elastin adsorption and selective hydrolysis of elastase}

After $20 \mathrm{mg}$ orcein elastin and $20 \mathrm{mg}$ BTP were separately added to $1 \mathrm{~mL}$ of enzyme solution $(150 \mathrm{U} / \mathrm{mL})$, the mixtures were incubated in an ice-water bath for $20 \mathrm{~min}$. Then the elastase enzyme activity (EEA) was measured using each of the supernatants. The adsorption rate (AR) was calculated by the formula as follows: $\mathrm{AR}=\left(\mathrm{EEA}_{\mathrm{Control}}\right.$ $\left.-\mathrm{EEA}_{\text {Sample }}\right) / \mathrm{EEA}_{\text {Control }} \times 100 \%$. Furthermore, for the characterization prior to hydrolysis, the elastase (after $60 / 120$-folds dilution) was added to the reaction systems as follows: (1) $10 \mathrm{mg}$ orcein elastin; (2) $10 \mathrm{mg}$ orcein elastin $+10 \mathrm{mg}$ casein; (3) $10 \mathrm{mg}$ orcein elastin $+10 \mathrm{mg}$ gelatin; (4) $10 \mathrm{mg}$ orcein elastin + $10 \mathrm{mg}$ BSA.

\section{Hydrolysis of different proteins by the purified elastase and by papain}

Elastase and papain, which have the same hydrolysis activity toward casein, were used to hydrolyze $20 \mathrm{mg}$ of each protein as follows $\left(40^{\circ} \mathrm{C}, 30 \mathrm{~min}\right)$ : orcein elastin, casein, gelatin, BSA, bovine hemoglobin, isolated soybean protein, and feather meal. After adding $2 \mathrm{~mL}$ of $10 \%$ (400 mM) trichloroacetic acid followed by centrifugation $(10 \mathrm{~min}$ at $9000 \mathrm{rpm})$, the absorbance at $680 \mathrm{~nm}\left(\mathrm{~A}_{680}\right)$ of the supernatant was measured by the Lowry method [17].

\section{Statistical analysis}

Data were analyzed using the unduplicated two-factor analysis of variance. A $P$ value of 0.05 was considered to be significant, and a $P$ value of 0.01 was considered to be extremely significant.

\section{Results}

\section{Morphologic identification of the strain producing elastase}

On the LB medium plate, the single colony of strain WZE87 appeared golden in color, wet and viscous on the surface, and round in shape after $24 \mathrm{~h}$ of incubation at $37{ }^{\circ} \mathrm{C}$. Cells were characterized as gram-negative, in the absence of flagella or spores, and 3.1-3.7 $\times 9.0 \mu \mathrm{m}$ in size under a light microscope. After $60 \mathrm{~h}$ of cultivation on the BTP medium, the BTP, which in the hydrolysis halo has the highest $\mathrm{HC}$ value (4.0), was completely hydrolyzed to be transparent. Additionally, its initial elastase activity of crude enzyme culture was $71.06 \mathrm{U} / \mathrm{mL}$.

\section{Physiological and biochemical identification of bacteria}

Furthermore, the strain WZE87 was tentatively identified as Chryseobacterium indologenes from the physiological and biochemical characteristics (Table 1). In order to confirm the identity, a full $16 \mathrm{~S}$ rDNA sequence with $1484 \mathrm{bp}$ in length was amplified and determined on GenBank (Accession No. HQ848390). The blasting result indicated that the strain WZE87 showed 97-99\% identity with Chryseobacterium indologenes. Therefore, we concluded that strain WZE87 is a strain of Chryseobacterium indologenes.

\section{Purification of elastase}

According to the supernatant activities of the enzyme sample after ammonium sulfate precipitation (Fig. 1), 30 and $60 \%$ ammonium sulfate saturation were chosen for gradient precipitation. Then, the final precipitate was dissolved in Buffer A, and the solution was dialyzed against Buffer A. Afterward, the dialysate was applied to a Q-Sepharose column. As shown in Fig. 2, elastase activity was detected at two active peaks. The stronger active fractions (Peak 1) were pooled and concentrated by PEG20,000 at $4{ }^{\circ} \mathrm{C}$. Finally, the enzyme solution was subjected to a Sephadex G-75 column. The proteins were eluted as one wide peak (Peak 1) and two sharp peaks (Peak 2 and Peak 3) (Fig. 3). Because the elastase activity was detected in Peak 2 only, its fractions were pooled, concentrated, freeze-dried, and stored at $-20{ }^{\circ} \mathrm{C}$. The results of the elastase purification are summarized in Table 2. By a three-step procedure, this enzyme with $2376.5 \mathrm{U} / \mathrm{mg}$ 
Table 1 Physiological and biochemical identification of $C$. indologenes

\begin{tabular}{|c|c|c|c|}
\hline Index & Result & Index & Result \\
\hline Ala-Phe-Pro-Arylamidase & + & Glu-Gly-Arg-Arylamidase & + \\
\hline Adonitol & - & Saccharose/sucrose & - \\
\hline L-Pyrrolydonyl-Arylamidase & + & D-Tagatose & - \\
\hline L-Arabitol & - & D-Trehalose & - \\
\hline D-Cellobiose & - & Citrate (sodium) & + \\
\hline$\beta$-Galactosidase & - & Malonate & - \\
\hline $\mathrm{H}_{2} \mathrm{~S}$ production & - & 5-Keto-D-Gluconate & - \\
\hline$\beta$-N-Acetyl-Glucosaminidase & + & L-Lactate alkalinization & - \\
\hline Glutamyl arylamidase pNA & + & $\alpha$-Glucosidase & + \\
\hline D-Glucose & - & Succinate alkalinization & - \\
\hline Gamma-Glutamyl-Transferase & + & $\mathrm{N}$-Acetyl-Galactosaminidase & - \\
\hline Fermentation/glucose & - & $\alpha$-Galactosidase & - \\
\hline$\beta$-Glucosidase & + & Phosphatase & + \\
\hline D-Maltose & - & Glycine arylamidase & + \\
\hline D-Mannitol & - & Ornithine decarboxylase & - \\
\hline D-Mannose & - & Glu-Gly-Arg-Arylamidase & + \\
\hline$\beta$-Xylosidase & - & Saccharose/sucrose & - \\
\hline$\beta$-Alanine arylamidase pNA & - & D-Tagatose & - \\
\hline L-Proline arylamidase & + & D-Trehalose & - \\
\hline Lipase & + & Citrate (sodium) & + \\
\hline Palatinose & - & L-Malate assimilation & - \\
\hline Tyrosine arylamidase & + & Ellman & - \\
\hline Urease & - & L-Lactate assimilation & - \\
\hline D-Sorbitol & - & & \\
\hline
\end{tabular}

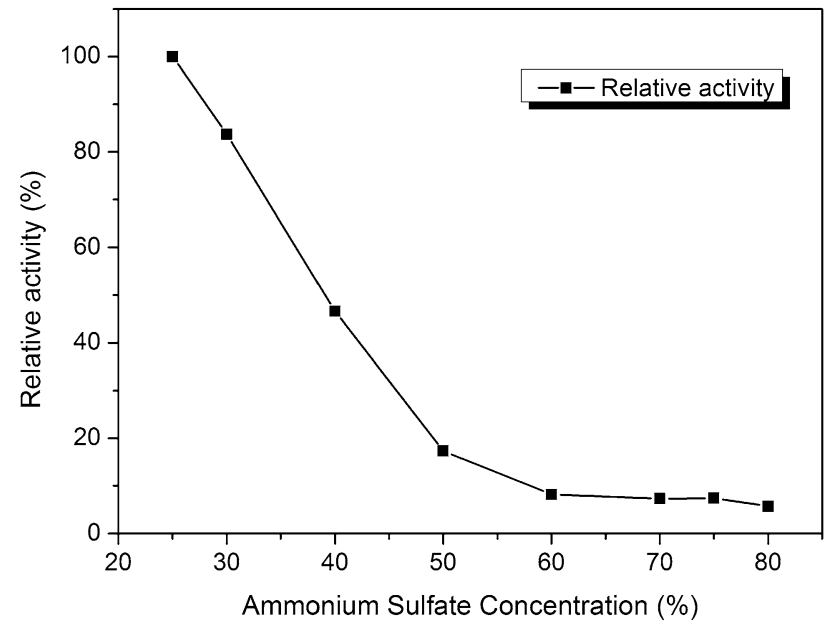

Fig. 1 Relative activity of the supernatant from ammonium sulfate precipitation

relative activity was purified 8.3 -fold with a recovery ratio of 5.8\% from the crude extract. As seen from the SDSPAGE analysis, elastase from $C$. indologenes WZE87 was purified to homogeneity with the relative molecular mass 26 kDa (Fig. 4).

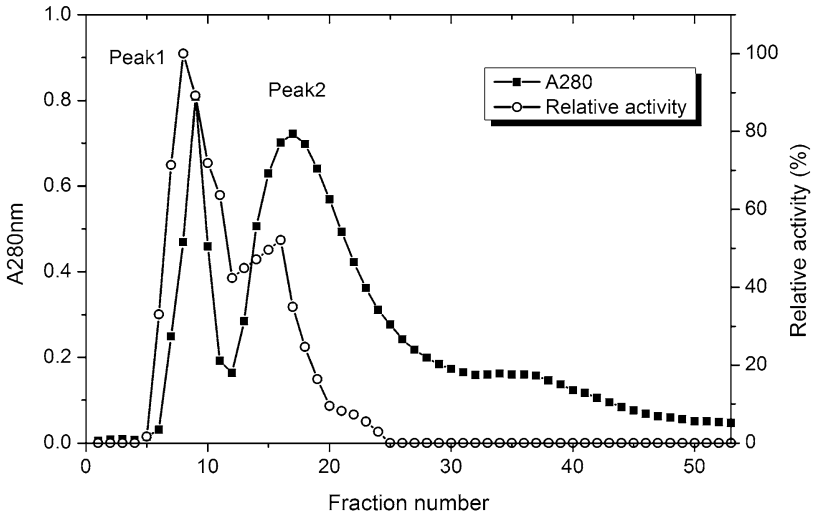

Fig. 2 Elution curve from Q-Sepharose column at $A_{280}$

\section{Effect of temperature on enzyme activity and stability}

The optimum activity of the enzyme was observed at $37^{\circ} \mathrm{C}$ (Fig. 5A). When the elastase was treated at $50{ }^{\circ} \mathrm{C}$ or at lower temperatures for $30 \mathrm{~min}$, the residual enzyme activity remained over $85 \%$ of the original enzyme activity. However, the enzyme activity dropped sharply by about $90 \%$ of the full enzyme activity when at $60{ }^{\circ} \mathrm{C}$ for $30 \mathrm{~min}$, 


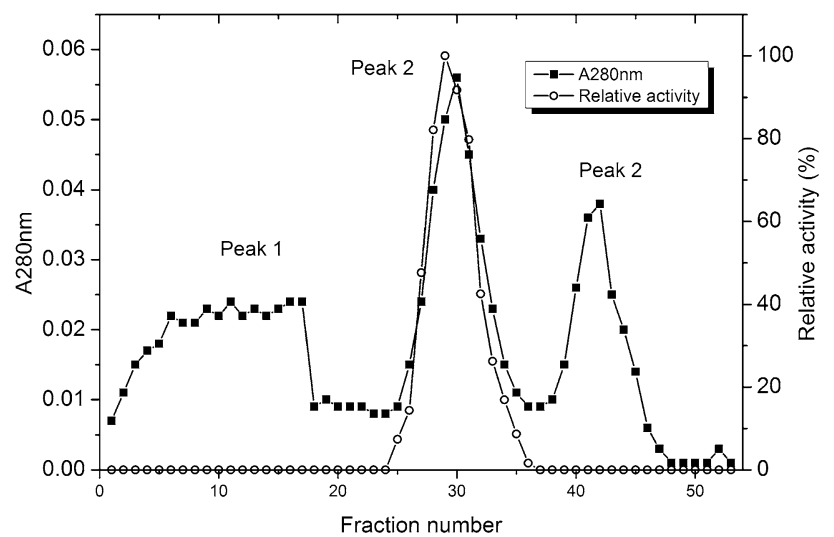

Fig. 3 Elution curve from Sephadex G-75 at $\mathrm{A}_{280}$

and the enzyme activity was completely lost at temperatures over $70{ }^{\circ} \mathrm{C}$ (Fig. 5B).

\section{Effect of pH on enzyme activity and stability}

The optimal reaction $\mathrm{pH}$ for the elastase was obtained at $\mathrm{pH} 7.5$ in Tris- $\mathrm{HCl}$ buffer and at $\mathrm{pH} 7.7$ in boric acid buffer (Fig. 6A). The $\mathrm{pH}$ optimal stability was determined in a $\mathrm{pH}$ range of 5.0-10.6 (Fig. 6B). After $30 \mathrm{~min}$ of incubation at $37^{\circ} \mathrm{C}$, the peak of residual enzyme activity was observed at pH 6.4 with $84 \%$ of activity. According to the results, the residual enzyme activity remained at over $70 \%$ of activity in all tests of $\mathrm{pH}$ stability $(72.5-84 \%)$, and there is no significant difference in different $\mathrm{pH}$, except at the optimal $\mathrm{pH}$.

\section{Effect of metal ions and reagents on enzyme activity}

Most of the metal ions exhibited a significant inhibition effect on the elastase (Table 3). Some of the metal ions such as $\mathrm{Fe}^{2+}, \mathrm{Fe}^{3+}$, and $\mathrm{Zn}^{2+}$ almost completely inhibited the enzyme activity, while the $\mathrm{Mn}^{2+}$ ion showed a sharp inhibition of the enzyme by $63 \%$. Further, $\mathrm{Ca}^{2+}, \mathrm{K}^{+}, \mathrm{Na}^{+}$, and $\mathrm{Li}^{+}$appeared to inhibit the elastase slightly, but only $\mathrm{Mg}^{2+}$ increased its activity marginally. Additionally, the elastase activity was drastically inhibited about $31-56 \%$ by the reagents including SDS, EDTA, and $\beta$ mercaptoethanol.

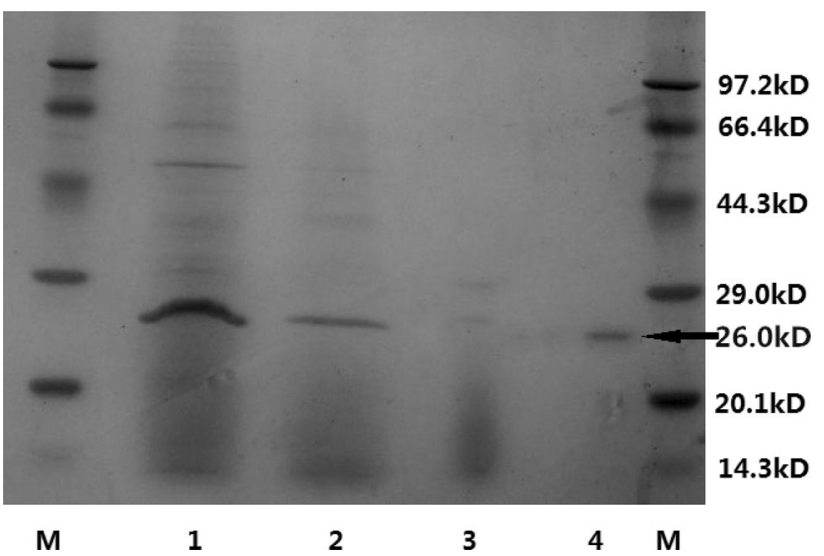

Fig. 4 SDS-PAGE of elastase from $C$. indologenes strain WZE87. (Lane M: low-molecular-weight protein marker; lane 1: crude enzyme solution; lane 2: concentrated sample from ammonium sulfate precipitation; lane 3: active peaks from Q-Sepharose column; lane 4: active peaks from Sephadex G-75 column)

\section{Effect of substrate adsorption on selective hydrolysis}

The adsorption rate of elastase toward insoluble substrates was likely to affect its hydrolysis ability. As seen in Table 4, the elastase showed a significant adsorption to elastin. 39\% orcein elastin and 30\% BTP were absorbed by the elastase. Meanwhile, both in high and low concentrations (60/120-folds dilution), casein and gelatin remarkably affected the selective hydrolysis of the elastase $(P<0.05)$ (Fig. 7A). However, BSA showed no significant effect on the selective hydrolysis of the elastase $(P>0.05)$.

\section{Elastase versus papain of hydrolysis activity to animal protein}

In order to evaluate the potential application of bacterial elastase in foodstuff industry, $C$. indologenes elastase and papain were used to degrade edible proteins (Fig. 7B). The result showed that the two enzymes have the similar hydrolytic characteristics toward the different proteins, and the relative activity was as follows: soybean-isolated protein $>$ BSA $>$ gelatin $>$ bovine hemoglobin $>$ feather meal. However, the relative activity of elastase to elastin could reach up to $69.7 \%$, and it was not detected in the

Table 2 Purification of elastase from $C$. indologenes strain WZE87

\begin{tabular}{lccccc}
\hline Purification steps & Total protein $(\mathrm{mg})$ & Total activity (U) & Specific activity (U/mg) & Purification (fold) & Recovery (\%) \\
\hline Crude extract & 206.03 & $58,719.12$ & 285 & 1 & 100 \\
Ammonium sulfate precipitation & 43.8 & $19,972.99$ & 456 & 1.6 & 34.9 \\
Q-Sepharose & 6.85 & $13,470.53$ & 1966.5 & 6.9 & 23 \\
Sephadex G-75 & 1.44 & 3422.17 & 2376.5 & 8.3 & 5.8 \\
\hline
\end{tabular}




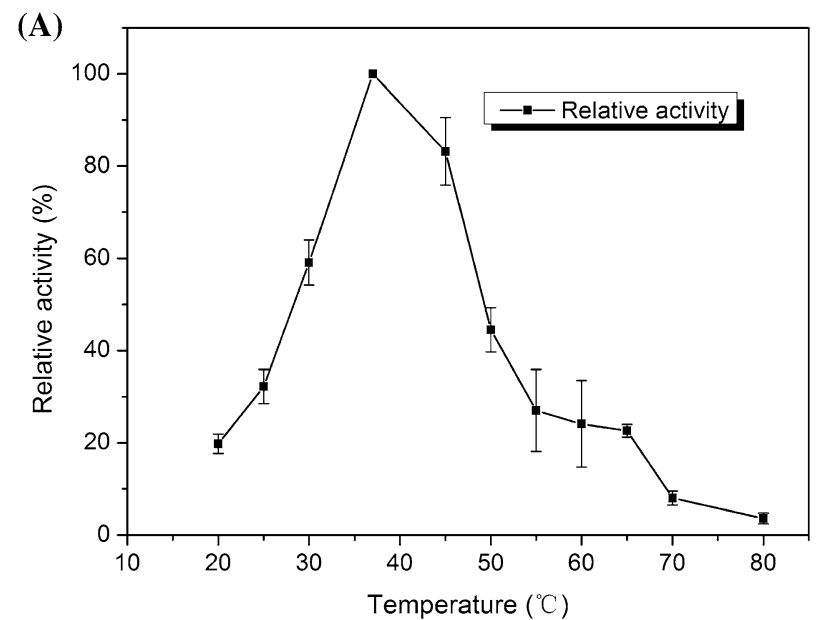

(B)

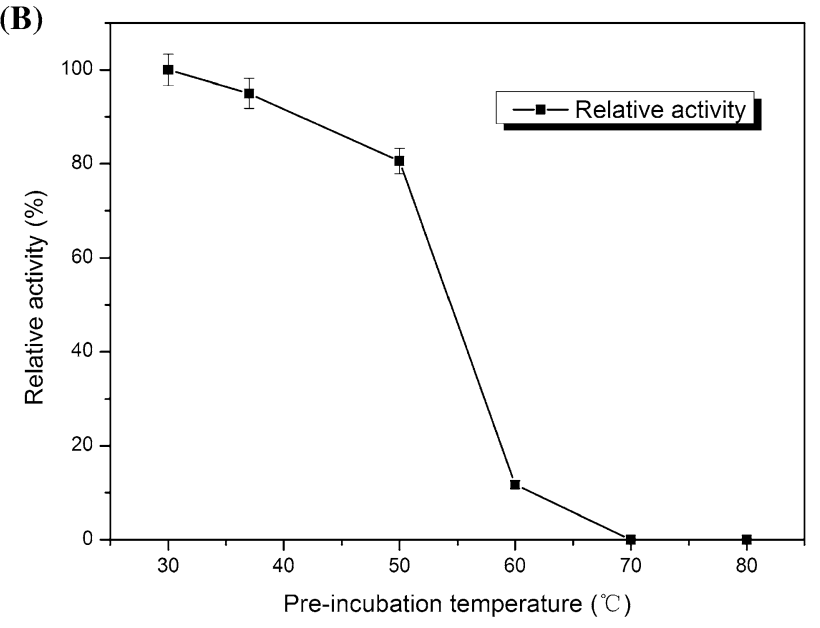

Fig. 5 Effects of temperature on C. indologenes elastase activity (A) and thermal stability (B)

papain-elastin group. Hence, the elastase in this research may have a similar but better hydrolytic characteristic than papain.

\section{Discussion}

Elastase was initially extracted from animal viscera, but this source cannot satisfy the requirements of industrial and daily use. Actually, microorganism isolation of elastase with high activity is an important and direct way to attain more elastase. Ying et al. isolated an elastase with $18 \mathrm{U} / \mathrm{mL}$ activity from Pseudomonas bacteria [1]. Fang et al. [18] attained an elastase with $74.25 \mathrm{U} / \mathrm{mL}$ activity from Bacillus subtilis. Chen et al. isolated an elastase with up to 100 $\mathrm{U} / \mathrm{mL}$ initial enzyme activity from Bacillus sp. [19]. In this study, we isolated a new elastase-active strain, Chryseobacterium indologenes, and its initial enzyme activity was $71.06 \mathrm{U} / \mathrm{mL}$. Compared with other elastases reported, elastase of this strain has a relatively high natural enzyme
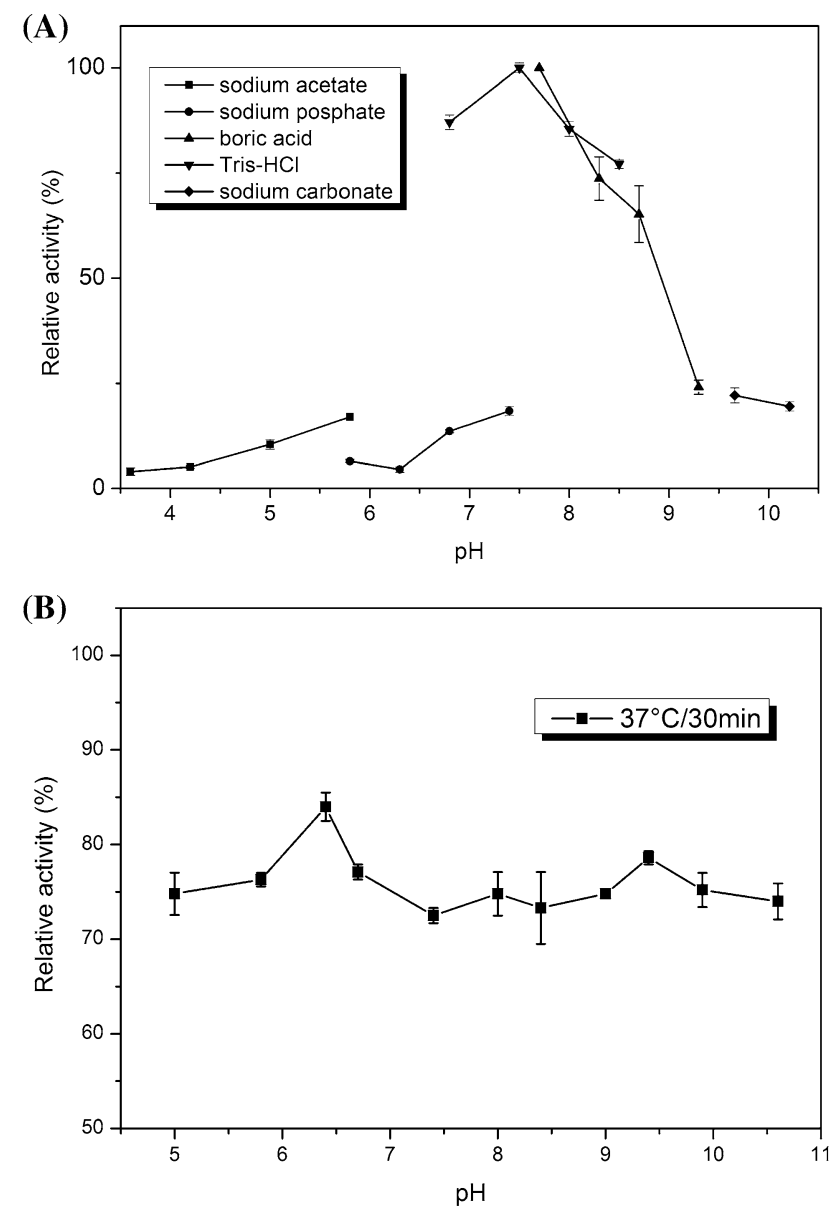

Fig. 6 (A) Effects of $\mathrm{pH}$ on elastase from C. indologenes. (B) $\mathrm{pH}$ stability of elastase from $C$. indologenes

Table 3 Effects of chemicals and reagents on elastase from $C$. indologenes

\begin{tabular}{|c|c|c|}
\hline Reagent & Concentration $(\mathrm{mM} / \mathrm{L})$ & Relative activity (\%) \\
\hline CK & 0 & 100 \\
\hline EDTA & 5 & 66.7 \\
\hline SDS & 5 & 44.1 \\
\hline$\beta$-Mercaptoethanol & 0.01 & 69.4 \\
\hline $\mathrm{KCl}$ & 5 & 85.9 \\
\hline $\mathrm{NaCl}$ & 5 & 77.5 \\
\hline $\mathrm{LiCl}$ & 5 & 96.4 \\
\hline $\mathrm{ZnCl}_{2}$ & $5 / 0.05$ & $7.2 / 24.5$ \\
\hline $\mathrm{MnCl}_{2}$ & 5 & 36.9 \\
\hline $\mathrm{CaCl}_{2}$ & 5 & 86.5 \\
\hline $\mathrm{MgCl}_{2}$ & 5 & 102.7 \\
\hline $\mathrm{FeCl}_{2}$ & 5 & 0 \\
\hline $\mathrm{FeCl}_{3}$ & 5 & 0 \\
\hline
\end{tabular}

activity. Furthermore, the specific activity of the purified elastase was $2376.5 \mathrm{U} / \mathrm{mg}$, which is higher than the reports 
Table 4 Elastin adsorption of elastase from $C$. indologenes

\begin{tabular}{llll}
\hline Index & Control group & Orcein elastin & BTP \\
\hline Supernatant enzyme activity (U) & 146 & 89 & 102 \\
Adsorption rate & - & $39 \%$ & $30 \%$ \\
\hline
\end{tabular}

(A)

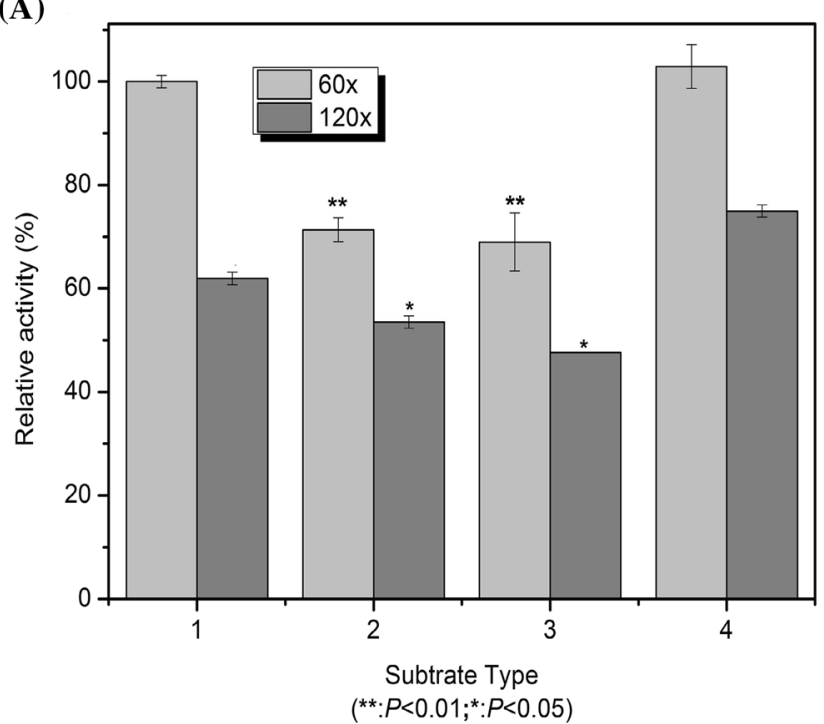

Fig. 7 (A) Elastin degradation by $C$. indologenes elastase alone or in a mixture with other proteins (1) Orcein elastin; (2) orcein elastin + casein; (3) orcein elastin + gelatin; (4) orcein elastin + BSA. (B) Effects of elastase and papain on different proteins'

of Chen et al. (292 U/mg) and Olfa et al. (81 U/mg) [20, 21], and similar to that reported by Han et al. [22] (2427 U/mg). Additionally, as a monomeric enzyme, SDSPAGE analysis showed that the molecular weight of the elastase was $26 \mathrm{kDa}$, which was different from all reported microbial elastases [23].

Reaction temperature and $\mathrm{pH}$ are two crucial parameters of protease industrial production. The optimal reaction temperature and $\mathrm{pH}$ of reported microbial elastases were generally higher than $45{ }^{\circ} \mathrm{C}$ and $7.0[14,24-26]$, respectively. The elastase in our research was thermostable below $60{ }^{\circ} \mathrm{C}$, but its optimal reaction temperature was $37^{\circ} \mathrm{C}$. So, it may be used in physianthropy and other fields as pancreatic elastase. Meanwhile, it has a wide range of $\mathrm{pH}$ stability ( $\mathrm{pH}$ 5.0-10.5) with high residual enzyme activity (72.5-84\%). Hence, this elastase could be applied to tenderize the elastin-rich tissues of food animals.

Further in the study, $5 \mathrm{mM} \mathrm{Mg}^{2+}$ slightly activated this enzyme, while $5 \mathrm{mM} \mathrm{Li}^{+}, \mathrm{Na}^{+}, \mathrm{Ca}^{2+}, \mathrm{K}^{+}$, EDTA and $0.01 \mathrm{mM} \beta$-mercaptoethanol inhibited it indistinctively. This differs from the results of Tsai et al. and Chen et al. who reported that $\mathrm{Ca}^{2+}$ could stabilize the activity of the enzyme and $\mathrm{K}^{+}$could activate the elastase $[19,26]$. Generally, SDS improved the elastase activity, but $5 \mathrm{mM}$ SDS

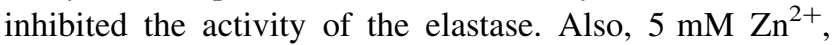

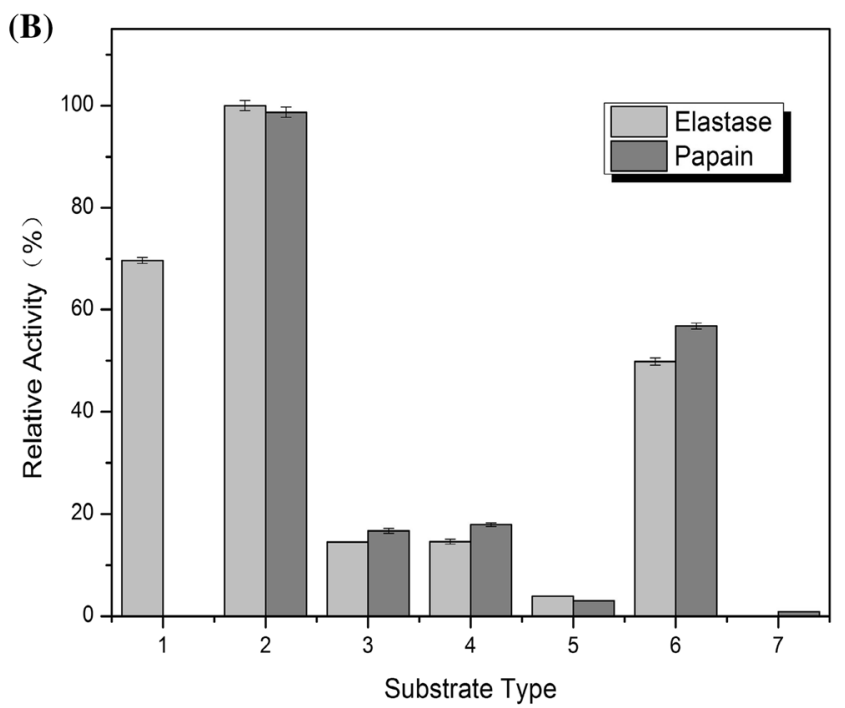

degradation as measured by the Lowry method. (1) Orcein-elastin; (2) casein; (3) gelatin; (4) BSA; (5) bovine hemoglobin; (6) soybeanisolated protein; (7) feather meal

$\mathrm{Fe}^{2+}$ and $\mathrm{Fe}^{3+}$ significantly reduced the activity of this enzyme, which is consistent with the reports of Yan et al. and Liu et al. [17, 27]. To determine whether the previous concentration of $\mathrm{Zn}^{2+}$ which inactivated this elastase (residual activity $7.2 \%$ ) was too high in the test, $0.05 \mathrm{mM}$ $\mathrm{Zn}^{2+}$ was utilized in further analysis. However, it still inhibited the activity (residual activity $24.5 \%$ ). Thus, it can be seen that elastase from Chryseobacterium indologenes is not a metalloproteinase [28]. However, EDTA, as a lowconcentration metal-ion-chelating agent, inhibited the activity of this elastase significantly. This showed that a certain kind of metal ion was crucial in the stabilization of elastase activity, which needs to be further investigated. Additionally, the inhibitory activity of $\beta$-mecaptoethanol toward this elastase indicated the existence of a disulfide bond. Hence, the distinctive enzyme properties of the elastase in this research manifest that it was a new microbial elastase.

Elastase is a broad spectrum proteolytic enzyme which is capable of hydrolyzing insoluble protein. Chen et al. [6] reported that the tenderization effect of recombinant elastase was better than commercial papain on pork shear force and tenderization rate. Kanako et al. [24] purified and crystallized an elastase named KFP 419, which the relative activity of elastin/casein of it was higher than that of 
poronase. In the current research, when coexisting with other substrates, elastin was selectively hydrolyzed by the elastase. According to the substrate specificity, this elastase can hydrolyze elastin while papain cannot hydrolyze elastin. This is significantly important for the tenderization of food animal tissues which are rich in elastin, such as bovine stomach and cowheels. Moreover, the elastase and papain showed no remarkable hydrolysis difference to the substrates $(P>0.05)$, although the elastase slightly hydrolyzed the feather meal.

In summary, a novel elastase was isolated and purified from Chryseobacterium indologenes in this study. Due to its specific hydrolysis toward elastin, the elastase has a foreseeable application in meat tenderization. Ultimately, the intensive investigation of this elastase should focus on hydrolysis optimization and food safety evaluation for its industrialization and commercialization.

Acknowledgments This work was supported by the Laboratory of Biochemistry and Molecular Biology, Sichuan Agricultural University, P. R. China. We thank the team of Native English Editing (Native EE) for critical reading and editing of this manuscript.

\section{References}

1. Yan ZY, Guan GX, Zhang WQ, Lin ZF (1995) Extracellular elastase produced bacteria screening and enzyme purification. Acta Microbiol Sin 35:50-55

2. Ying WJ, Zhang CL, Zhang SX (2007) Screen and optimization of fermentation conditions of research on elastase from bacteria. J Biol 24:49-52

3. Clark DJ, Hawrylik SJ, Kavanagh E, Opheim DJ (2000) Purification and characterization of a unique alkaline elastase from Micrococcus luteus. Protein Expres Purif 18(1):46-55

4. He GQ, Chen QH, Ju XJ, Shi ND (2003) Influence of medium components on elasetase production using crude sources by Bacillus sp. EL3140. J Zhejiang Univ Sci 4:142-151

5. Robert L, Robert AM, Jacotot B (1998) Elastin-elastaseatherosclerosis revisited. Atherosclerosis 140(2):281-295

6. Chen ZJ, Wang L, Xu WT, Gu XX, Li XT, Mei XH, Huang KL (2010) Application of recombinant elastase in pork tenderization. Food Sci 31(7):42-45

7. Sachar LA, Winter KK, Sicher N, Frankel S (1995) Photometry method for estimation of elastase activity. Proc Soc Expeti Bio Med 90:323-326

8. Balo J, Banga I (1950) The elastolytic activity of pancreatic extracts. Biochem J 46:384-386

9. Banga I (1952) Isolation and crystallisation of elastase from the pancreas of cattle. Acta Physiol Acad Sci Hung 3(2):317-424

10. Erlendsson LS, Filippusson H (1998) Purification and characterization of ovine pancereatic elastase. Comp Biochem Physiol 120(3):549-557
11. Gunnar IB, Smalas AO, Qutzen H, Nils PW (1998) Purification and characterization of pancreatic elastase from North Atlantic salmon (Salmo salar). Mol Mar Biol Biotech 7(2):105-114

12. Stevenson KJ, Voordouw JK (1975) Characterization of trypsin and elastase from the Moose (Alces alces). I. Amino acid composition and specificity towards polypeptides. Biochem Biophys Acta 386(1):324-331

13. Ines M, Betty BC (1960) Bacterial elastase I. Isolation, purification and properties. Arch Biochem Biophys 91(1):47-53

14. Frosco M, Chase T, Macmillan JD (1992) Purification and properties of the elastase from Aspergillus fumigatus. Infect Immun 60(3):728-734

15. Weber K, Osborn M (1969) The reliability of molecular weight determination by dodecyl sulphate polyacrylamide gel electrophoresis. J Biol Chem 244:4412-4416

16. Marion MB (1976) A rapid and sensitive method for the quantitation of microgram quantities of protein utilizing the principle of protein-dye binding. Anal Biochem 72:248-254

17. Liu YF, Chen JL, Wang JY, Yu C, Qu XJ, Sun JH, Xia HH (2003) The physical and chemical properties of the Bacillus subtilis elastase. Biotechnol 13(2):28-29

18. Fang SL, Li SJ, Zhang NN (2006) Selecting high elastase-producing Bacillus subtilis with physical mutagenesis method. Food Drug 8(10):44-49

19. Chen QH, He GQ, Wu YL (2003) Screening of elastase-producing strains and primary studies on fermentation conditions. J Zhejiang Univ (Agric Life Sci) 29(1):59-64

20. Chen QH, He GQ, Jiao YC, Ni H (2006) Effects of elastase from a Bacillus strain on the tenderization of beef meat. Food Chem 98:624-629

21. Olfa GB, Ben KH, Ahmed B, Islem Y, Noomen H, Kemel J, Moncef N (2012) Pseudomonas aeruginosa A2 elastase: purification, characterization and biotechnological applications. Int $\mathrm{J}$ Biol Macromol 50:679-686

22. Han MH, Ding HY, Wang JL, Jin MY, Yu XB (2013) Expression of the lasB gene encoding an organic solvent-stable elastase in Pichia pastoris and potential applications of the recombinant enzymes in peptide synthesis. Biochem Eng J 77:154-160

23. Wang SL, Hsu WT, Liang TW, Yen YH, Wang CL (2008) Purification and characterization of three novel keratinolytic metalloproteases produced by Chryseobacterium indologenes TKU014 in a shrimp shell powder medium. Bioresour Technol 99:5679-5686

24. Kanako M, Noriko Y, Tomeo Y, Yukiko K, Michiyo K, Kan K (2000) Purification and crystallization of a new Bacillus subtilis elastase. J Home Econ Jpn 51(12):1127-1135

25. Shiio I, Ozaki H (1974) Microbial Production of elastolytic enzyme. Agri Biol Chem 38(1):1-7

26. Tsai YC, Lin SF, Li YF, Yamasaki M, Tamura G (1986) Characterization of an alkaline elastase from alkalphillic Bacillus YaB. Biochim Biophys Acta 883:439-447

27. Xu Y, He GQ, Li JJ (2005) Effective extraction of elastase from Bacillus sp. fermentation broth using aqueous two-phase system. J Zhejiang Univ Sci 6B(11):1087-1109

28. Kazuyuki M, Hiroshige T (1967) Elastolytic properties of various proteinases from microbial origin. Arch Biochem Biophys 120:68-78

29. Lowry OH, Rosebrough NJ, Farr AL, Randall RJ (1951) Protein measurement with the Folin phenol reagent. J Biol Chem 193:265-275 